\title{
Sanitation Practices of Street Food Vendors in
}

\section{Cabanatuan City}

\author{
June Jay Irvin B. Pula, Marilou P. Pascual
}

Department of Hospitality Management, Nueva Ecija University of Science and Technology, Cabanatuan City, Philippines Maloupascual797@y ahoo.com, pbalaria@yahoo.com

Abstract- This study delved on the sanitation practices of street food vendors in Cabanatuan City. It employed descriptive research design which involved the vendors and their customers. Majority of street food vendors belonged to the age bracket 30 to 39 years, have had at least finished secondarylevel of education, married, hadmore than ten yearsof experience as a street food vendor; and spent fourto eight hours per day invending activities. Their attendanceto food safety and sanitationtrainings had either none, or only one to four trainings to some. Findings further revealed that self-assessments of the respondent-street food vendors on the areas of cleanliness such as hand sanitation, proper work attire, and personal health and hygiene; and food preparation, display, and storagewere consistently higher than the assessmentsmade by their customers. Likewise, strong correlation between the respondents' profile and their sanitation practices was only found in the length of experience.

Keywords-street food vendors, sanitation practices, food hygiene.

\section{INTRODUCTION}

The City of Cabanatuan is a first class component city in Nueva Ecija, Philippines. The continuing progress in the city and the numerous economic and cultural activities has encouraged the spread of an informal trade of street food vending, especially in areas where pedestrian traffic is high. Street food enterprises are usually small, necessitate simple cooking skills and facilities, and offer potential for generating income and employment (Winarno and Allain, n.d.). However, the capabilities of these street food vendors to provide suitable food sanitation to their product are questionable due to the unregulated nature of this food service sector. Dra. Veritas F. Luna of the Department of Food Science and Nutrition of the College of Home Economics, University of the Philippines, emphasizes the lack of sufficient policies and regulations, street food vendors will not practice safe food handling (Defensor, 2006).

In Good Hygienic Practices in the Preparation and Sale of Street Food in Africa (FAO, 2009), the primary factors of food contamination are the following: the improper care of ingredients,display, and foodproduct storage, theutensils used in preparing, cooking, and storing food productswhich are often inadequate, the poor conditions of food storage, and the incorrect temperatures that allows the development of bacterial pathogens.
Buted and Ylagan (2014) have found that the expectations of customers that should be prioritized by vendors are cleanliness of the work area and environment, cooked foods should be separated from raw ones, and the utensils used. This includes the proper work attire, personal hygiene, and some other practices which may be considered uns anitary.

In another study conducted by Balaria et al. (2015) foodborne pathogen present in a barbecue sample tested in the laboratoryof the Department of Science and Technologywas S. aureus that could be harmful and could cause diarrhea. In the same study, the sample buko juice contained E. coli. Further interpretation mage by a government doctor on the latter showed that any amount would not be desirable, and would depend on one's tolerance or reaction to this when ingested.

In Cabanatuan City, despite the proliferation of street food vending activities, there is a dearth of literature on the sanitation practices of street food vendors. Hence this study focused on the sanitation practices of street vendors in Cabanatuan City.

Specifically, it sought to answer the following:

1. How may the profile of the street food vendors be described?

2. What is the assessment of the respondents on thesanitation practices of street food vendors? 
3. Is there a significant difference between the responses of the two groups of respondents?

4. Is there a significant relationship between the profile of the respondents and their assessment on their sanitation practices?

\section{METHODOLOGY}

The study employed the descriptive method of research. Descriptive research answers the needs of the study since the study attempted to describe the profile of street food vendors and examined their sanitary practices. Purposive sampling was used in the study and the 14 respondents were chosen based on the following criteria (Subia, 2018a): a street food vendor and with more than 11 months of working experience. There were two research instruments used in the study. The first research instrument is a two-part questionnaire. The first part gathered data related to the demographics of the respondents, while the second part featured statements that describe sanitary practices. A five-point scale, which indicates the degree of agreement of respondents on the said statements, was used.

The scale used in responding the items in the questionnaires is shown below.

$\begin{array}{ccc}\text { Scale } & \begin{array}{c}\text { Verbal } \\ \text { Description }\end{array} & \begin{array}{c}\text { Verbal } \\ \text { Interpretation } \\ \text { Strong Agreement }\end{array} \\ 5 & \text { Always } & \text { Agreement } \\ 4 & \text { Often } & \text { Moderate } \\ 3 & \text { Sometimes } & \text { Agreement } \\ 2 & \text { Seldom } & \text { Disagreement } \\ 1 & \text { Never } & \text { Strong Disagreement }\end{array}$

The second research instrument is a developed Observation Guide for the selected customers of the street food vendors to triangulate data gathered from the first research instrument. This observation guide featured statements that were parallel to the second-part of the first research instrument.

The data gathered were analyzed using the following descriptive measure of statistics: weighted mean, percentage, t-test, and Pearson product-moment correlation test.

The agreements of the respondent's to the statements that describedthe street food vendors' sanitary practices were determined using the scale given by the table below.
Table.1: Scale for Interpretation of Responses in the Assessment Form

\begin{tabular}{c|c|c}
\hline Scale & Verbal Description & $\begin{array}{c}\text { Verbal } \\
\text { Interpretation }\end{array}$ \\
\hline $4.20-5.00$ & Always & Strong Agreement \\
\hline $3.40-4.19$ & Often & Agreement \\
\hline $2.60-3.39$ & Sometimes & Moderate Agreement \\
\hline $1.80-2.59$ & Seldom & Disagreement \\
\hline $1.00-1.79$ & Never & Strong Disagreement \\
\hline
\end{tabular}

\section{RESULTS AND DISCUSSIONS}

On the description of the profile of the street food vendor-respondents.

In terms of age, there were a total of fourteen (14) respondents of which $35.7 \%$ were from the ages of 30 to 39 years, $28.6 \%$ were aged from 40 to 49 years, $21.4 \%$ were from the age bracket of 50 to 59 years, and $14.3 \%$ were from the ages to 20 to 39 years. The gender of the respondents was equally distributed at 50\% male and 50\% female.

Majority of the respondents had secondarylevel as their highest educational attainment (64.3\%), followed by tertiary level (14.3\%) and non-degree (14.3\%). $7.1 \%$ of the respondents only had elementary level education.

A highpercentage of the respondents weremarried (64.3\%). $35.7 \%$ of the respondents declared their civil status as single.

The respondents have had varying length of experiences measured in years as a food vendor: $35.7 \%$ have more thanten years; $28.6 \%$ of them havehad one to three years; $21.4 \%$ have four to six years; while $14.3 \%$ have seven to nine years.

The respondents were evenly split onthe number oftrainings attended on food safety and sanitation: 50\% have had no trainings at all, while the other $50 \%$ have had attended one to four trainings on the said topics.

The following percentages describedthe distribution of the respondents in terms of the number of hoursthey spenton a daily basis invending activities: $50 \%$ spent four to eight hours, $42.86 \%$ spent more than eight hours, and $7.14 \%$ spent less than four hours.

The respondents possessed differing permits relative to the street food vending activities. Only $7.1 \%$ of them have a permit from the City Health Office. $35.7 \%$ of them have street food permits. $57.1 \%$ of them have permits from various government units. 
On the assessment of the two groups of respondentsas regard the street food vendors' sanitation practices.

On hand hygiene practices. There were fifteen (15) statements in the research instrument that describe the practices as regard the item hand hygiene. Customers' overall WM is 1.42 , while vendors' overall WM is 4.18 . This indicates strong disagreement on the customers' assessment and that of the vendors. This discrepancy may be explained by the attention that food clients give to food handlers whereas food handlers have, in general, a high regard on the status of their hygiene practices (FAO, 2007).

On proper work attire. Twelve (12) statements were in the research instrument that describes the practices as regard the item proper work attire. The customers' assessment computed mean was 1.92 which signifies their strong disagreement to the statements that described the vendors' proper work attire as against the vendors' assessment computed over-all mean of 3.13 which got a moderate agreement to the same statements.

On personal health and hygiene. There were eighteen (18) statements in the research instrument that describe the practices as regard the item personal health and hygiene practices. The customers' assessment computed over-all mean of 1.81 reveals that they had disagreement with the statements that described the vendors' personal health and hygiene practices. The vendors' assessment computed over-all mean of 2.00 also reveals that they had disagreement with the statements that described their personal health and hygiene practices.

On food preparation, display, and storage. Twenty (20) statements in the research instrument described practices on food preparation, display, and storage. The customers' assessment computed over-all mean of 2.46 reveals that they had disagreement with the statements that described the vendors' food preparation, display, and storage practices. The vendors' self-reported assessment computed over-all mean of 4.20 reveals that they had strong agreement with the statements that described their food preparation, display, and storage practices.

Is there a significant difference between the responses of the two groups of respondents?

Table 2: $t$-Test on Assessments on Sanitation Practices

\begin{tabular}{c|c|c}
\hline $\begin{array}{c}\text { Difference in } \\
\text { Sanitation } \\
\text { Practices }\end{array}$ & $\begin{array}{c}\text { Vendors } \\
\text { Assessment }\end{array}$ & $\begin{array}{c}\text { Customers } \\
\text { Assessment }\end{array}$ \\
\hline Mean & 3.3890 & 1.8523 \\
\hline Variance & 0.2224 & 0.0209 \\
\hline t stat & \multicolumn{2}{|c}{$11.46^{* *}$} \\
\hline $\begin{array}{c}\text { t critical, } \\
\text { two-tailed }\end{array}$ & 2.12 \\
\hline
\end{tabular}

The determination of significant differences between the respondents' actual practices as against their self-assessment was done through a t-test at a confidence level of $1 \%(\alpha=0.01)$. There is significant difference in the assessment of the two groups of respondents regarding the sanitation practices of the vendors. The vendors rated their sanitation practices much higher than the customers did. A t value of 11.46 against a $t$ critical value of 2.12 signifies that there is significant difference in the assessment of the sanitation practices made by the respondents.

Is there a significant relationship between the profile of the respondents and their assessment of their sanitation practices?

Table.3: Pearson-r Correlation Table on Profile versus Sanitation Practices

\begin{tabular}{c|c|c|c|c}
\hline Profile & $\begin{array}{c}\text { Sanitation Practices, } \\
\boldsymbol{r} \text {-value }\end{array}$ & $\boldsymbol{p}$-value & $\boldsymbol{\alpha}$-value & Interpretation \\
\hline Age & 0.150 & 0.608 & 0.05 & No significant relationship \\
\hline Gender & -0.077 & 0.794 & 0.05 & No significant relationship \\
\hline Highest Educational Attainment & 0.072 & 0.808 & 0.05 & No significantrelationship \\
\hline Civil Status & 0.098 & 0.739 & 0.05 & No significant relationship \\
\hline Length ofExperience & $0.594^{*}$ & 0.025 & 0.05 & Significant relationship \\
\hline Time Spent per Day in Vending Activities & 0.083 & 0.778 & 0.05 & No significant relationship \\
\hline Possession of Permits & 0.046 & 0.875 & 0.05 & No significant relationship \\
\hline
\end{tabular}

*correlation is significantat 0.05 level 
There were eight factors in the respondents' demographic profile that were considered in establishing relationships with their sanitation practices. These were their age, gender, highest educational attainment, civil status, length of experience as a street food vendor, number of trainings attended on food safety and sanitation, number of hours per day spent on street food vending activities, and possession of permits relevant to their street food vending. The respondents' sanitation practices hinged upon the four factors of hand hygiene, proper work attire, personal health and hygiene, and food preparation, display and storage.

Table 3 establishes the Pearson-r correlation between these variables of which it was found that only the vendor's length of experience has significant relationship with their sanitation practices. This implies that the longera vendor stays in the food-service business, his performance of sanitation practices is more assured.

\section{CONCLUSIONS}

Based on the results of the study, the following conclusions are drawn:

1. Majority of street food vendors in Cabanatuan Citybelong to the age range of 30 to 39 years, have had at least secondary level educational attainment, married, have more than ten years of experience as a street food vendor; and spent four to eight hours per day in vending activities. Gender distribution among them is equal. Their attendance to food safety and sanitation trainings are either none, or from one to four trainings.

2. The self-reported assessments of the respondent street food vendors on the areasof food hygienesuch ashand hygiene, proper work attire, and personal health and hygiene;, and food preparation, dis play, and storage are consistently higher than the assessments made by their customers.

3. Significant difference between assessments of the respondents on the sanitation practices of street food vendors was found.

4. Significant relationship between the respondents profile and their sanitation practices was only found in the variable length of experience.

\section{RECOMMENDATIONS}

Based on the results of the study, and the conclusions drawn, these recommendations are offered:

1. The results of this study can be used as a basis for awareness campaign on sanitation practices of street food vendors;
2. Sanitation training programs should be conducted immediately by concerned agencies with the participation of State Universities and Colleges who have the capability to conduct such;

3. The Local Government Unit especially the Department of Health should be vigilant in ensuring that this sector abides by its current policies, and intensify its campaign on proper food sanitation;

4. They should further regulate this food industry by making accurate decisions given available information (Subia, 2018b) particularly by amending and/or adding more laws to protect the consuming public;

5. Similar researches be undertaken that willfurther appraise the sanitation practices of the foodservices industry.

\section{REFERENCES}

[1] Agjencia e Ushqimit dhe Veterinarisë (AUV) (n.d.). Good Hygiene Practices. Retrieved from Http://www.fao.org

[2] Aquino, John Paulo L., Charmain C. Pedalgo, Alfonso Rey N. Zafra., and Troy P. Tuzon. The Perception of Local Street Food Vendors of Tanauan City, Batangas on Food Safety. LPU-LagunaJournal of International Tourism and Hospitality Management, Vol. 3, No. 1, September 2015.

[3] Balaria, F. et al. (2015) Bacteriological Content of StreetVended Food: A Case of Cabanatuan Vendors. CMBT Research Journal, Vol. 5, p.43.

[4] Buted, Dexter R. and Alex P. Ylagan. Street Food Preparation Practices. Asia Pacific Journal of Education, Arts and Sciences, Vol. 1, No. 2, May 2014). Retrieved from http://www.ajpeas.apjmr.com

[5] Calderon, J.F. and E.C. Gonzales (2004). Methods of Research and Thesis Writing. Mandaluyong City, Manila: National Bookstore.

[6] Centers for Disease Control and Prevention (CDC). Multiple-Serotype Salmonella Gastroenteritis Outbreak After a Reception - Connecticut, 2009. Morbidity and Mortality Weekly Report, Vol. 59, No.34, September 3, 2010. Retrieved from https://www.cdc.gov

[7] Chukuezi, Comfort O. Food Safety and Hygienic Practices of Street Food Vendors in Owerri, Nigeria. Studies in Sociology of Science, Vol. 1, No. 1, 2010, pp.50-57.

[8] Dealino-Tanquezon, Dahlia. Personal Hygiene Practices Among Street Food Vendors in Intramuros, Manila. The Macrotheme Review, 4(2), SI II2015.

[9] Defensor, Jude (2006). Dirty Dining (All About Philippine Street Food, Safety, and Nutrition). Men's Health Philippines. $\quad$ Retrieved from https://judefensor.wordpress.com/

[10] Fonbuena, Carmela (2008, July 4). Makati, Cabanatuan, Tagbilaran are RP's Best Cities to Live In. Newsbreak. Retrieved from http://archives.newsbreak-knowledge.ph 
[11] Food and Agriculture Organization of the United Nations (FAO), (2009). Good Hygienic Practices in the Preparation and Sale of Street Food in Africa: Tools for Training. Retrieved from http://www.fao.org

[12] Food and Agriculture Organization of the United Nations (FAO), (2007). Promises and Challenges of the Informal Food Sector in Developing Countries. Retrieved from http://www.fao.org

[13] Gonzales, Darren J. (2016, July 28). Origin: Cabanatuan. Retrieved from https://darrengonzales.wordpress.com/

[14] Hammond, Linda, et al (2003). Learning From Others: Learning in Social Context". Retrieved from http://www.google.com

[15] Magpayo, Prudencio E. (2014, December 7). Cabanatuan Enjoys Economic Boom. Business Mirror. Retrieved from http://www.businessmirror.com.ph/

[16] Muinde, OK and E Kuria. Hygienic and Sanitary Practices of Vendors of Street Foods in Nairobi, Kenya. African Journal of Food Agriculture and Nutritional Development, Vol.5, No.1., 2005.

[17] Sincero, Sarah Mae. (2011) "Domains of Learning" Retrieved from https://explorable.com/domains-of-learning

[18] Subia, G. (2018a) Comprehensible Technique in Solving Consecutive Number Problems in Algebra. Journal of Applied Mathematics and Physics, 6, 447-457. doi: 10.4236/jamp.2018.63041.

[19] Subia, Gener S. (2018b). Think Like My Teacher (TLMT): A New Method in Assessing Millennial Learners. International Journal of Arts, Humanities and Social Sciences. Volume 3. Issue 1.www.ijahss.com

[20] United States Food and Drug Administration (USFDA) (2005).Employee Health and Personal Hygiene Handbook. Retrieved from https://www.fsis.usda.gov

[21] Winarno, F.G. and Al. Allain (n.d.). Street Foods in Developing Countries: Lessons from Asia. FAO Corporate Document Repository. Retrieved from http://www.fao.org/

[22] (2011, September 8). Cabanatuan City Still Philippines' "Tricycle Capital". PhilStar Global. Retrieved from http://www.philstar.com 